\title{
INDOOR RADON RELATED WITH THE GEOLOGY IN ROMANIAN URBAN AGGLOMERATIONS (CLUJ-NAPOCA)
}

\author{
Ștefan FLORICĂ ${ }^{1,2 *}$, Tiberius DICU1', Bety-Denissa BURGHELE', \\ Mircea MOLDOVAN ${ }^{1}$, Kinga SZACSVAI ${ }^{1}$, Anca ȚENTER ${ }^{1}$, \\ Botond PAPP ${ }^{1}$, Simion BELDEAN ${ }^{1}$, Andrei ISTRATE ${ }^{1}$, \\ Tiberiu CATALINA ${ }^{1}$, Arthur TUNYAGI ${ }^{1}$, Cristina HORJU-DEAC ${ }^{1}$, \\ Andreea RĂCHIȘAN ${ }^{1}$, Teofana SFERLE ${ }^{1}$, Gabriel DOBREI', \\ Carlos SAINZ ${ }^{1}$, Alexandra CUCOȘ ${ }^{1}$
}

${ }^{1}$ Babeş-Bolyai University, Faculty of Environmental Science and Engineering, "Constantin Cosma" Radon Laboratory, 400294 Cluj-Napoca, Fântânele No. 30, Romania

${ }^{2}$ Babes-Bolyai University, Faculty of Biology and Geology, Department of Geology, 400084, Cluj-Napoca, Mihail Kogalniceanu nr.1.

${ }^{*}$ Corresponding author: stefan_stefan2121@yahoo.com

\begin{abstract}
Radon is a natural radioactive gas that occurs due to the radioactive decay of radium $\left({ }^{226} \mathrm{Ra}\right)$ present in rocks which, in turn, cames from the radioactive decay of uranium $\left({ }^{238} \mathrm{U}\right)$, a primordial natural element. Along with factors such as porosity, permeability and humidity of the rocks and soils, pressure and temperature, geology setting plays one of the most important roles in the release of radon into the environment. Depending on the mineralogical compositions and characteristics of the bedrock from a certain area, a higher or lower concentration of radioactive minerals can be found in the rocks, which will directly influence the level of radon in the atmosphere, implicitly the concentration of radon measured in houses. In this study, a six months concentration of radon $\left({ }^{222} \mathrm{Rn}\right)$ was assessed in 256 houses from Cluj-Napoca area using CR-39 nuclear track detectors. Correlations between the indoor radon levels and the geological setting was further analyzed. The aim is to better understand the influence of geology on the concentration of radon levels in homes, in order to further identify other risk areas in terms of exposure to radon. Further investigation is needed on other factors influencing the accumulation of radon in high concentrations indoor, such as ventilation, occupation patterns or constructive and architectural features for typical houses. Therefore, the results of this work are considered to be important for indoor radon management in Romania.
\end{abstract}

Key words: indoor radon, radon exposure, indoor air quality

\section{INTRODUCTION}

Radon is a natural radioactive gas, considered to be the main contributor to the total dosage received by population from natural background radiation. Due to its radioactivity and short lived radioactive disintegration products, it is also considered 
to be a health hazard. Far more, it is largely recognized that long term exposure to radon in homes and workplaces is the main leading cause of lung cancer, second to smoking (Darby et al., 2005; Field et al., 2006, Council Directive 2013/59 /Euratom; WHO 2009). Geology is considered, by far, the most important factor controlling the source and distribution of radon. This, due to the fact that most of natural uranium $\left({ }^{238} \mathrm{U}\right)$ where the radon $\left({ }^{222} \mathrm{Rn}\right)$ comes from, is encapsulated in rocks in the form of minerals. Nevertheless, several other natural and anthropogenic factors such as weather conditions, building materials, the degree of containment in the areas where individuals are exposed, outside air, tap water and even city gas, the architecture, ventilation and the environmental parameters of the building and the soil (temperature, pressure, relative humidity) and occupation patterns can influence the indoor radon levels (Darby et al., 2005; Field et al., 2006, Council Directive 2013/59 /Euratom; WHO 2009; www.irart.ro; www.smartradon.ro; Cosma and Jurcuţ, 1996; Cosma et al., 2013; Cucoş et al., 2015; Cucoş et al., 2017).

Reducing exposure to radon in buildings is a key priority of public health protection against radiation. Directive 2013/59 / Euratom is demanding an increased attention to residential radon by implementing rules in each European country, beginning in 2018, and serious approach to monitoring and mitigating actions.

Since September 2016 we have started a research pilot project entitled SMART-RAD-EN, funded by the Competitiveness Operational Programme 2014-2020 of Romania, to be implemented up to the year 2020. The project aims to develop and implement energy efficient solutions for controlling and reducing exposure to radon in residential buildings located in the main urban agglomerations of Romania (Bucureşti, Cluj-Napoca, Timişoara, laşi and Sibiu).

The present paper reports the results for the first measurement campaign of indoor radon concentration during six months, in 256 houses from Cluj-Napoca area, by using CR-39 nuclear track detectors. Some basic correlations between the indoor radon levels and the geological setting were analyzed. The aim of this study is to better understand the influence of the geology on the concentration of radon levels in homes.

\section{MATERIALS AND METHODS}

\section{Geological data}

Various detailed studies were focused on the geology of the Cluj-Napoca city area (e.g. Răileanu and Saulea, 1956; Maxim et al., 1960; Mészáros, 1960; Mészáros and Clichici, 1976; Popescu et al., 1978 etc.). The region which the city belongs to comprises a large diversity of rocks and lithostratigraphic units involving: magmatic, metamorphic and sedimentary rocks (Fig. 1).The metamorphicsole is the oldest structure in the area (Precambrian). It is mostly formed in the basal part by paragneiss, quartz and mica schist, with quartzite, amphibolite and crystalline limestone interleaving. The upper levels bear mica schist with black and white mica. The first sedimentary rocks overlying the sole are Late Cretaceous reworks in the basal section crystalline schist, than bear sandstones, clay, limestone and polygenic conglomerates. All these rocks are 
overlain by a transgressive Cenozoic sedimentary succession (Paleogene, Neogene and Quaternary).Andesitic and dacitic dykes were reported from the western part of the studied area (Mészáros and Clichici, 1976).

The Paleogene starts with lowermost Paleocene red beds, probably including the $\mathrm{K} / \mathrm{T}$ boundary, if considering the situation from the Jibou Formation type section area (Codrea and Godefroit, 2008). Classical stratigraphic charts of the region are in Codrea et al., 2010 (and references therein). In this regard, the basal continental Paleogene formation is overlain by marine rocks, documenting a Lutetian transgression, the marine realm continuing until Priabonian. Gypsum beds are largely exposed. They are followed by various marl, limestone and sandstone deposits (Raileanu \& Saulea, 1956; Mészáros and Moisescu, 1991; Popescu et al., 1978). In Late Priabonian, terrestrial environments occurred again, with red beds (Valea Nadășului Formation). Various marls, bioclastic limestone's, clays, coaly schists, and shallow water limy sedimentary rocks accumulated in the latest Eocene and Lower Oligocene.

The Oligocene of this region is nothing but alternating marine and continental formations, with various rocks, either clastic, or carbonatic (Codrea et al., 2010, and references therein).

Glauconitic and mica rich clays and tuffs occur in Early Miocene (AquitanianBurdigalian). In Middle Miocene (Badenian-Sarmatian), gypsum, salt and marls are the most common rock, but the clastic ones occur too (Filipescu, 2001). In Quaternary, the Someș and Nadașului river terraces were formed. Nowadays, alluvial deposits (sand-sand gravels) continue to accumulate.

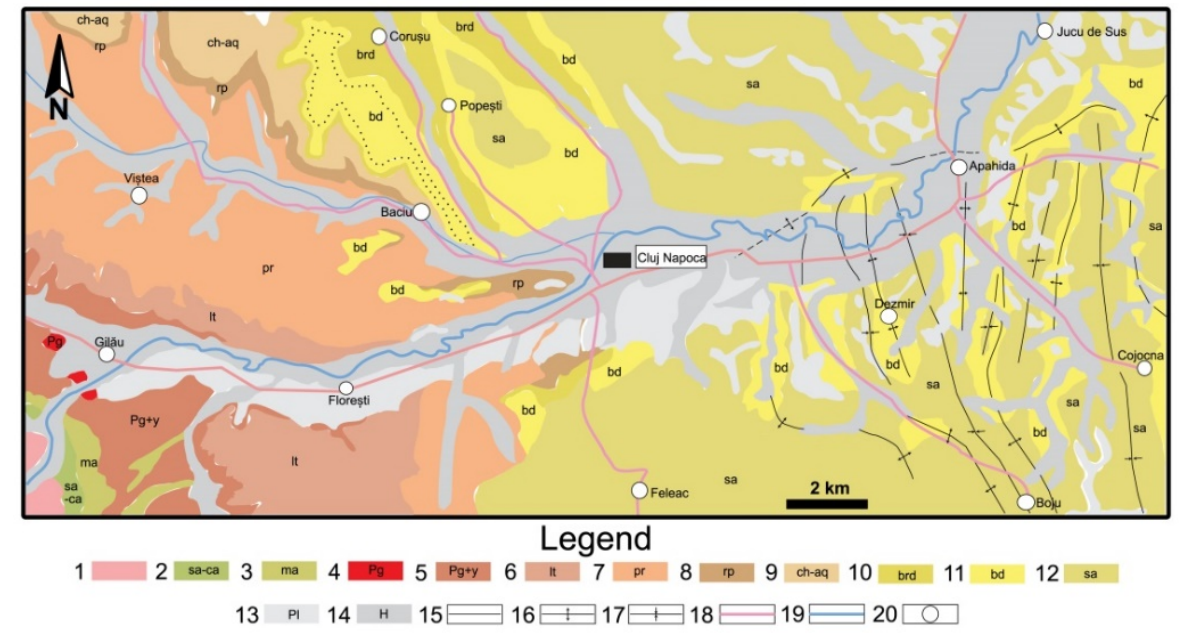

Fig. 1. Geological map of Cluj-Napoca Area (modified after IGR map, L-34-XII, 1:200 000) 1: Proterozoic, 2: Cretaceous (Santonian-Campanian), 3: Cretaceous (Maastrichtian), 4: Paleogene andesitic dykes, 5: Paleogene (Paleocene-Ypresian), 6: Eocene (Lutetian), 7: Eocene (Priabonian), 8: Oligocene (Rupelian), 9: Oligocene-Miocene (Chattian-Aquitanian), 10: Miocene (Burdigalian), 11: Miocene (Badenian), 12: Miocene (Sarmatian), 13: Quaternary (Pleistocene), 14: Quaternary (Holocene), 15: faults, 16: Syncline axis, 17: Anticline axis, 18: Roads, 19: Rivers, 20: Locality 
Ș. FLORICĂ, T. DICU, B.D. BURGHELE, M. MOLDOVAN, K. SZACSVAI, A. TEENTER, B. PAPP, S. BELDEAN, A. ISTRATE, T. CATALINA, A. TUNYAGI, C. HORJU-DEAC, A. RĂCHIȘAN, T. SFERLE, G. DOBREI, C. SAINZ, A. CUCOȘ

\section{Indoor radon}

Passive indoor radon measurements were performed by using CR-39 nuclear track detectors exposed for 6 months. Subsequently, the detectors were safely transported (storage in another room could affect the measurement accuracy) to the Radon Laboratory for processing. Processing, analysis and comprehensive evaluation of the measurement results were achieved in cooperation with the manufacturer, according to the specific protocol and calibration factors. After exposure, the developing and automatic reading protocol was applied by using the RadoSys-2000 equipment (Elektronika, Budapest, Hungary), under optimum conditions. The concentration of radon was determined by counting the traces of alpha particles resulting from the decay of radon on a given area. Individual errors for radon measurements by this method are less than $10 \%$. The accuracy of this passive method of detection is being periodically verified by successful participation in international intercomparison campaigns (Cucoş et al., 2012; Cosma et al., 2013; Cosma et al., 2015).

Qualitative assessment of indoor air quality conditions, health and comfort of residents was done through questionnaires, applied to each resident of the investigated homes, according to the model of RADPAR (Radon Prevention and Remediation). Through the questions was determine the details of how the building is used, occupation program, occupants opinions on air quality and functioning of the systems in the house, periods of overheat or winter comfort, in order to analyse possible correlations between the level of radon and other household air pollutants and specific characteristics of energy-efficient houses. The questionnaire also requests general information about residents health and behaviour, smoking status, location and building structure, facilities and materials used, as well as information about the energy performance of buildings: the type of exterior wall insulation, exterior facade status, number of levels, heating sources (boiler, stove), windows type (double wooden windows, double glazing, triple glazing) existing ventilation systems, winter and summer temperature, air quality, draughts, building's energy consumption, etc.

\section{RESULTS AND DISCUSSION}

Summary statistic of radon concentration measurements in air of residential premises from Cluj-Napoca are presented in Table 1.

The data distribution type, within the investigated cities, is a log-normal distribution, aspect confirmed by applying the D'Agostino-Pearson statistical test on the log-transformed data $(p>0.05)$.

Table 1. Descriptive statistic for indoor radon concentration in houses from Cluj-Napoca area under SMART_RAD_EN project

\begin{tabular}{|c|c|c|c|c|c|c|c|}
\hline Nhouse & $\begin{array}{c}\mathbf{C}_{\text {Rnmin }} \\
\left(\mathbf{B q} / \mathbf{m}^{3}\right)\end{array}$ & $\begin{array}{c}\mathbf{C}_{\text {Rnmax }} \\
\left(\mathbf{B q} / \mathbf{m}^{3}\right)\end{array}$ & $\begin{array}{c}\text { A.M. } \\
\left(\mathbf{B q} / \mathbf{m}^{3}\right)\end{array}$ & $\begin{array}{c}\text { S.D. } \\
\left(\mathbf{B q} / \mathbf{m}^{3}\right)\end{array}$ & $\begin{array}{c}\mathbf{G . M} . \\
\left(\mathbf{B q} / \mathbf{m}^{3}\right)\end{array}$ & $\begin{array}{c}\mathbf{C . V} . \\
(\%)\end{array}$ & $\begin{array}{c}\text { No. } \\
\mathbf{3} \mathbf{3 0 0} \mathbf{B q} / \mathbf{m}^{3}\end{array}$ \\
\hline 256 & $5(21)$ & 720 & 139 & 133 & 95 & 96 & 43 \\
\hline
\end{tabular}


From the 256 houses selected for the present study in the metropolitan area of Cluj-Napoca, 43 presented concentrations higher than $300 \mathrm{~Bq} / \mathrm{m}^{3}$. Given that the computed averages refer only to a period of six months of monitoring - and are not annual concentrations - it is necessary to apply a seasonal correction factor, in order to evaluate the annual values. Thus, by applying the seasonal correction factor, from the 256 monitored houses, a total of 52 have annual mean for indoor radon concentration superior to the threshold value.

The distribution of indoor radon results for the city of Cluj-Napoca within Campaign I indicate that $17 \%$ of the investigated residential dwellings present values higher than the European reference level of $300 \mathrm{~Bq} / \mathrm{m}^{3}$ for residential radon (Tollefsen et al., 2014), while $20 \%$ of the investigated houses register radon levels higher than $250 \mathrm{~Bq} / \mathrm{m}^{3}$ (figure 2).

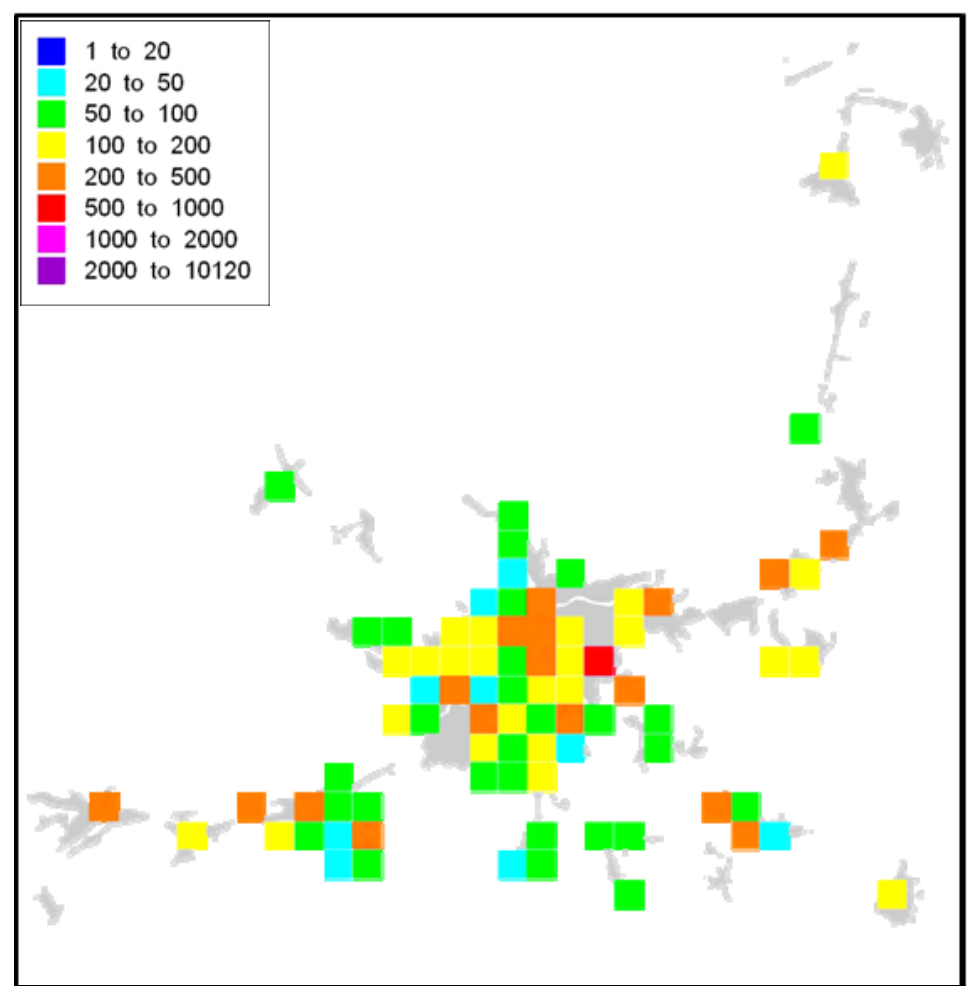

Fig. 2. The indoor radon map for houses of Cluj-Napoca under the SMART_RAD_EN project

The average for all measurements performed for the concentration of indoor radon within accommodations monitored in this project, is $138 \mathrm{~Bq} / \mathrm{m}^{3}$, higher than the values reported for other countries, and higher than the value of $98 \mathrm{Bg} / \mathrm{m}^{3}$, reported as average exposure to indoor radon for Europe (Tollefsen et al., 2014), 
and comparable with the values registered for the Czech Republic and Estonia $\left(140-160 \mathrm{~Bq} / \mathrm{m}^{3}\right)$, which can be explained through the existing resemblances in relief and geology.

The rock types that are most likely to cause elevated indoor radon levels in some countries, are considered to have uranium concentrations greater than $2 \mathrm{ppm}$ (Gundersen et al., 1992). In this regard, some examples can be given by some magmatic (granites, riolites, andesites and basalts), metamorphic (gneiss and some schists) and sedimentary (argillaceous schists and clays) rocks. For Romania, the most radioactive sedimentary rocks are considered to be clays (with an average uranium concentration of $3.3 \mathrm{ppm}$ ), sandstones (with an average uranium concentration of $3 \mathrm{ppm}$ ) and argillaceous schists (with an average uranium concentration of $3 \mathrm{ppm}$ ) (Cosma et Jurcuț, 1996; Stoici et Tătaru, 1988). However, lower or higher uranium values can be measured in all types of rocks, regardless of their origin.

For this assessment, the rock types that were more likely to cause the high levels of radon concentrations, measured in houses, are considered to be sedimentary rocks, which include clays and sandstone deposits, largely found into the Paleogene and Neogene bedrock assemblage. Although these sedimentary deposits are not uniformly distributed, decreasing in age from West to the East, clays and sandstones are widely spread in the whole geological complex.

Considering the geological context and the fact that the indoor radon concentration values are not evenly distributed in the houses, by not showing a pattern (figure 2), we can assume that even though the geological factors are responsible for the radon emissions, they are not the only ones to influence the indoor concentrations. Other factors that influence the concentration of indoor radon are represented by architectural details of houses.

\section{CONCLUSIONS}

The present paper report the results for the first measurement campaign of indoor radon concentration during six months in 256 houses from Cluj-Napoca area by using CR-39 nuclear track detectors. The preliminary indoor radon map for Cluj-Napoca area was plotted, taking into account the geological context. The aim of this pilot study is to better understand the influence of geology on the concentration of radon levels in homes.

The study shows that average indoor radon concentration for the surveyed area is $138 \mathrm{~Bq} / \mathrm{m}^{3}$. The indoor radon results indicate that $17 \%$ of the investigated residential dwellings present values higher than the European reference level of $300 \mathrm{~Bq} / \mathrm{m}^{3}$ for residential radon, while $20 \%$ of the investigated houses register radon levels higher than $250 \mathrm{~Bq} / \mathrm{m}^{3}$.

Even though the principal factor for high radon concentrations appear to be the geological bedding by the presence of rock type known to have relatively high radioactive contents (clays and sandstones), it is clear that there are other aspects to be considered. Those aspects can include some geological factors influenced by ground waters, climate change, permeability of soils and rocks, along with antropogenic factors. 
Further investigation is needed on other factors influencing the accumulation of radon in high concentrations indoor, such as ventilation, occupation patterns or constructive and architectural features for typical houses, together with soil radon measurements.

After carrying out the project activities, an inventory of indoor air pollution in conjunction with energy consumption will be completed for 1,000 houses from Bucharest, Cluj-Napoca, lasi, Sibiu and Timisoara, and also integrated into a geographic information system and processed for use in the air quality modelling.

\section{Acknowledgements}

The research is supported by the project ID P_37_229, Contract No. 22/ 01.09.2016, with the title „Smart Systems for Public Safety through Control and Mitigation of Residential Radon linked with Energy Efficiency Optimization of Buildings in Romanian Major Urban Agglomerations SMART-RAD-EN" of the POC Programme.

\section{REFERENCES}

Codrea A.V., Godefroit P., 2008, New Late Cretaceous dinosaur findings from northwestern Transylvania (Romania). Comptes Rendus Palevol, Paris, 7 (2008), pp. 289-295.

Codrea V., Jipa-Murzea C., Csiki Z., Barbu O., 2010, Maastrichtian dinosaurs in SW Transylvania (Romania). Scientific Annals, School of Geology, Aristotle University of Thessaloniki, Proceedings of the XIX CBGA Congress, Thessaloniki, Greece, Special volume 99, pp. 69-74.

Cosma C., Jurcuţ T., 1996, Radon and the surrounding environment. Dacia, Cluj-Napoca, $208 \mathrm{p}$.

Cosma C., Cucoş (Dinu) A., Dicu T., 2013, Preliminary results regarding the first map of residential radon in some regions in Romania, Radiation Protection Dosimetry 155, pp.343-350.

Cosma C., Papp B., Cucoș A., Sainz C., 2015, Testing radon mitigation techniques in a pilot house from Baita-Stei radon prone area (Romania). J. Environ. Radioact. 140, pp. 141-147.

Council Directive 2013/59/Euratom laying down basic safety standards for protection against the dangers arising from exposure to ionising radiation (http://www.ecolex.org/ecolex/ ledge/view/RecordDetails;DIDPFDSljsessionid=0143E1A4CE30CABFEEE93B0CE 3BBFFOF?id=LEX-FAOC130004\&index=documents).

Cucoș (Dinu) A, Cosma C., Dicu T., Begy R., Moldovan M., Papp B., Niță D., Burghele B., Sainz C., 2012, Through investigations on indoor radon in Băița radon-prone area (Romania). Science of Total Environment, 431, pp. 78-83.

Cucoş (Dinu) A., Dicu T., Cosma C., 2015, Indoor radon exposure in energy-efficient houses from Romania. Romanian Journal of Physics. 60 (9-10), pp.1574-1580.

Cucoş (Dinu) A., Papp B., Dicu T., Moldovan M., Burghele B.D., Moraru I., Tenter A., Cosma C., 2017, Residential, soil and water radon surveys in north-western part of Romania. Journal of Environmental Radioactivity, 166 (2), pp. 412-416. 
Ș. FLORICĂ, T. DICU, B.D. BURGHELE, M. MOLDOVAN, K. SZACSVAI, A. TEENTER, B. PAPP, S. BELDEAN, A. ISTRATE, T. CATALINA, A. TUNYAGI, C. HORJU-DEAC, A. RĂCHIȘAN, T. SFERLE, G. DOBREI, C. SAINZ, A. CUCOȘ

Darby S., Hill D., Auvinen A., Barros-Dios J.M., Baysson H., Bochicchio F., Deo H., Falk H., Forastiere F., Hakama M., Heid I., Kreienbrock L., Kreuzer M., Lagarde F., Mäkeläinen I., Muirhead C., Oberaigner W., Pershagen G., Ruano-Ravina A., Ruosteenoja E., Schaffrath (Rosario) A., Tirmarche M., TomáBek L., Whitley E., Wichmann H.E., Doll R., 2005, Radon in homes and risk of lung cancer: collaborative analysis of individual data from 13 European case-control studies. BMJ, doi:10.1136/bmj.38308.477650.63.

Field R.W., Krewski D., Lubin J.H., Zielinski J.M., Alavanja M., Catalan V.S., et al., 2006, An overview of the North American case-control studies of residential radon and lung cancer. Journal of Toxicology and Environmental Health, A (69), pp.599-631.

Filipescu S., 2001, Cenozoic lithostratigraphic units in Transylvania. In: Bucur I \& Săsăran E (eds.) - Calcareous algae from Romanian Carpathians. Field trip Guidebook. Presa Universitară Clujeană, pp. 37-48.

Gundersen L., Randall Schumann R., Otton J.K., Dubiel R.F., Owen D.E., Dickinson K.A., 1992, Geology of radon in the United States. Geological Society of America Special Paper, $271 \mathrm{p}$.

Maxim I. Al., Lucca V., Marincaș V., Clichici O., Șuraru N., Dușa A., Florei N., Șuraru M., Ionescu G., Moțiu A., Ghiurca V., Nicorici E., Băluță Cr., Ghergariu L., 1960, Calcarele grosiere de pe teritoriul orașului Cluj (Materiale de construcție), Studia Universitatis Babeş-Bolyai, Geologia-Geographia, Cluj, II (1), pp. 7-63.

Mészáros N., Clichici O, 1976, Pe poteci cu banuței de piatră. Ghid geologic al zonei Cluj. Ed. Sport-Turism, Bucuresti.

Mészáros N., Moisescu V., 1991, Bref apercu des unités lithostratigraphiques du Paléogène dans le Nord-Ouest de la Transylvanie (région de Cluj-Huedin), Roumanie. Bull. Inf. Géol. Bass., 28 (2), pp. 31-39.

Mészáros N., 1960. Studiul litofacial şi paleogeografic al depozitelor marine eocen medii de la vest şi sud-vest de Cluj. Studia Univ. Babeş-Bolyai, II (1), pp. 87-104.

Popescu B., Bombiţă G., Rusu A., Iva M., Gheţa N., Olteanu R., Popescu D., Tăutu E.,1978, The Eocene of the Cluj - Huedin area. D. S. Inst. Geol., 64 (4), p. 295 - 376.

Răileanu G., Saulea E., 1956, Paleogenul din regiunea Cluj şi Jibou (NV bazinului Transilvaniei). Anuarul Com. Geol., XXIX, pp. 272-308.

Stoici S.D., Tătaru S., 1988, Uraniul si Thoriul. Editura Tehnica București

Tollefsen T., Cinelli G., Bossew P., Gruber V., De Cort M., 2014, From the European indoor radon map towards an Atlas of natural radiation. Radiation Protection Dosimetry, $162(1-2)$, pp. 129-134.

WHO - World Health Organization, 1983, Indoor Air Pollutants: Exposure and Health Effects, EURO Rep. Stud., 78, pp.1-42.

WHO - World Health Organization, 2009, Handbook on indoor radon: a public health perspective, ISBN 9789241547673, pp.1-93. 